\title{
Sources of finance available for sme sector in Pakistan
}

\author{
Muhammad Mohsin Khan* \\ National Bank of Pakistan, Lahore, Pakistan \\ *E-mail address: mohsin_khan434@yahoo.com
}

\begin{abstract}
Small and medium enterprises (SMEs) are engines of growth for developed and developing countries. Developing countries like Pakistan must pay special attention towards its development and growth which is very essential for country's economic growth, economic development, employment generation, income equality, poverty alleviation, entrepreneurial culture etc. But unfortunately this sector is under performing due to many barriers including improper infra-structure, regulatory requirements difficulties, shortage of skilled HR, non competitive products, lack of entrepreneurial expertise, small scope of business and risk of default but above all access to finance is the major barrier that is facing by SMEs. This research paper examines the sources of finance (formal and informal) that are available for SMEs and also highlights the issues that create hindrance in effective flow of financial facilities to SMEs especially SEs (Small Enterprises). The research paper concludes that sufficient and easy availability of finance is the key to success for SMEs in Pakistan.
\end{abstract}

Keywords: Small and medium Enterprises; Small Enterprises; Formal Financial Sources; Informal Financial Sources; Access to Credit

\section{INTRODUCTION}

Small and Medium Enterprises (SMEs) are considered to be an effective tool for economic growth, economic development, poverty alleviation, income generation and employment generation. The role of SMEs for economic growth and development of any country is even more evident when the economies of developing countries are concerned. If we talk about the importance of SMEs in context of Pakistan, this sector is a backbone of Pakistan economy as this sector plays a significant role for economic development and considered as a survival in worst economic condition. According to IFC (2012), approximately there are 3.2M businesses in Pakistan of which $3 \mathrm{M}$ are SMEs so constituting more than $90 \%$ of business stakes and having economic contribution of more than $30 \%$ to GDP, $25 \%$ to country's total earnings and employing more than $70 \%$ of labor force. Keeping in view the importance of SME sector in Pakistan, many significant milestones have been achieved by all the stakeholders including establishment of Small and Medium Enterprises Development Authority (SMEDA), SME bank, SBP SME department, Prudential Regulations of SBP for SMEs and various government initiatives from time to time. Despite of all the significant efforts made by the stakeholders for its effective growth and development, this sector is facing many challenges including improper infra-structure, regulatory requirements difficulties, shortage of skilled HR, non competitive products, lack of entrepreneurial 
expertise, shortage / irregular availability of financing facilities, inability to meet financing formalities / credit conditions, lengthy documentation procedure, small scope of business and risk of default. Access to credit is one of the major issues that is facing by this sector, while conducting the research it was found that financing options for SMEs are numerous but access to finance is difficult despite various government/ regulator initiatives. This research paper is solely focusing in knowing the sources of finance available for SMEs in Pakistan both formal sources of finance and informal sources of finance and to highlight the challenges/ issues that are facing by the sector which hinder its growth.

The reason why I have chosen this topic is that I am associated with the banking field and working as a internal auditor in National Bank of Pakistan which has extended a good size of its advances portfolio to SMEs, further I have a interest in knowing about SMEs and issues related to it because as far as Pakistan is concerned where more than $90 \%$ of business stakes are SMEs and having economic contribution of more than $30 \%$ to GDP, $25 \%$ to country's total earnings and employing more than $70 \%$ of labor force, this sector is of paramount importance. My target audience will be the students of finance who want to learn about SMEs and the issues related to this sector, policy makers who can be able to know the issues relating to this sector and it is also a helping tool for researchers who want to research more on this very topic.

The significant role of small and medium enterprises (SMEs) in economic development and growth has been well documented in previous researches. Majority of the previous researches are about the importance of SMEs and if these are properly taken care of then they can be a real engines of growth and development for any country economy so very few researches are available that are exclusively focusing in knowing the sources of finance available for SME sector along with the issues/ challenges facing the sector. The objectives of this research paper shall specifically include the following;

○ To explore the formal sources of finance available for SMEs.

- To explore the informal sources of finance available for SMEs.

○ To analyze either these sources of finance (formal and informal sources of finance) are practically obtainable easily to SMEs and especially SEs (small enterprises)

- To highlight various issues/ challenges that are facing by this sector which are hindering its growth and easy access of finance.

- Finally, to come up with the conclusion and recommendations after the in depth analysis in literature review.

\section{LITERATURE REVIEW}

According to practitioners, academicians and other intellectuals SMEs are accepted as effective tool for economic growth, economic development, poverty alleviation, income generation, employment generation and income equality for both developing and developed countries. SMEs have played a significant role in the development of world economies and resultantly proved to be an engine of economic development and growth (Sas Aruwa, 2013). Kashif, Hamid and Abaid Ullah in 2006 concluded that SMEs have played a significant role for the development of world economies like Taiwan, Korea, Hongkong and other asian giants because SMEs are capable to harness the available sources in an efficient manner for the betterment of society (Hannah Galvin).

If we talk about the importance of SMEs in context of Pakistan, this sector is a backbone of Pakistan economy as this sector plays a significant role for economic development and 
considered as a survival in worst economic condition (Sherazi, Iqbal, Asif, Rehman \& Shah 2013).

Though its worldwide acceptance as one of the most effective tools for economic development its classification or definition differs from ' country to country (Gbandi and Amissah, 2014). SMEs are defined on the basis of size, amount of investment in assets, no. of employees and total annual turnover (Sas Aruwa, 2014). It is also defined on the basis of capital outlay, available plant and machinery, share in the market, fixed capital investment (Ogechukevu, 2009).

European Union defined SMEs as companies with less than 250 employees and revenues not over 50M euros (Fatai, 2011). According to economic development of USA if any entity has two or more characteristics from following features then that particular entity is a small business including managing the enterprise, working capital is supplied, individuals should be a owner and business operational area is small then the entity is considered to be small business (Sas Aruwa, 2013).

Based on the potential of this sector for the economic development of the country including employment generation, increasing income, poverty reduction, SBP issued separate prudential regulations for SMEs in 2003. But with passage of time it was analyzed by the regulator (SBP) that financial institutions' focus while serving this sector is tilting towards large scale companies thus neglecting small enterprises due to the non availability of data and risk of failure associated with small businesses. Kauser, Durrani, Hussain and Hasan (2012) pointed out that banks are promoting medium enterprises and neglecting the small enterprises which give rise to huge financial gap between small enterprises and medium enterprises, because near banks small enterprises have fewer options and facilities to grow and resultantly $75 \%$ of finance applications of small enterprises are rejected by banks where as $65 \%$ of applications of medium enterprises are accepted. Further banks and other financial institutions consider age of the business of SMEs, collateral that may be offered as security and SME size as important pillars for extending financing facility which apparently are not available with small enterprises. For this to give boost to the efforts being made for improving small enterprises' (SEs) access to finance, small enterprise (SEs) and medium enterprises (MEs) are separately defined, so the existing definition of SEs and MEs according to SBP PRs is as follows;

\subsection{Small Enterprises ${ }^{1}$}

An entity having number of employees up to 20 and annual sales turnover up to $75 \mathrm{M}$.

\subsection{Medium Enterprises ${ }^{2}$}

An entity ideally not a public limited company having number of employees from 21 to 250 , in case of manufacturing and service concern and 21 to 50 employees in case of trading concern and having annual sales turnover above Rs. $75 \mathrm{M}$ and up to Rs. $400 \mathrm{M}$ in case of all types of MEs. 
Table 1. SME definition by various institutions of Pakistan ${ }^{3}$.

\begin{tabular}{|c|c|c|}
\hline Institution & Small & Medium \\
\hline $\begin{array}{c}\text { Enterprise Development } \\
\text { Authority (SMEDA) }\end{array}$ & $\begin{array}{c}\text { 10-35 Employees or } \\
\text { Productive assets of Rs } \\
\text { 2-20 million }\end{array}$ & $\begin{array}{c}\text { 36-99 Employees or } \\
\text { Productive assets of Rs. } \\
20-40 \text { million }\end{array}$ \\
\hline SME Bank & $\begin{array}{c}\text { Total Assets of Rs. 20 } \\
\text { Million }\end{array}$ & $\begin{array}{c}\text { Total Assets of Rs. } \\
100 \text { million }\end{array}$ \\
\hline $\begin{array}{c}\text { Federal Bureau of } \\
\text { Statistics }\end{array}$ & Less than 10 employees \\
\hline $\begin{array}{c}\text { Sindh Industries } \\
\text { Department }\end{array}$ & $\begin{array}{c}\text { Fixed assets with Rs. 10 } \\
\text { million excluding cost of land }\end{array}$ & Same as for small \\
\hline $\begin{array}{c}\text { Punjab Small } \\
\text { Industries Corporation }\end{array}$ & $\begin{array}{c}\text { Fixed investment up to Rs. } \\
\text { 20 million excluding land and } \\
\text { building }\end{array}$ & N/A \\
\hline
\end{tabular}

${ }^{1}$ extracted from the PRs issued by SBP regarding SMEs

${ }^{2}$ extracted from the PRs issued by SBP regarding SMEs

${ }^{3}$ This Table is actually adapted from Table of SME Definitions used by various institutions in Pakistan ANNEXIII Developing SME Policy in Pakistan.

According to an estimate there are approximately 2M SMEs in Pakistan. These include 600,000 service concerns, 400,000 manufacturing and 1,000,000 trade concerns (Mehboob UL Hassan, 2008). According to IFC (2012), approximately there are $3.2 \mathrm{M}$ businesses in Pakistan of which $3 \mathrm{M}$ are SMEs so constituting more than $90 \%$ of business stakes and having economic contribution of more than $30 \%$ to GDP, $25 \%$ to country's total earnings and employing more than $70 \%$ of labor force.

It is now without any doubt that SMEs are an effective tool of economic development and growth in Pakistan, however this sector is facing many challenges and one of the major challenges faced by SMEs is capital to finance their operations. As mentioned by Hamid \& AbaidUllah, 2006 that SMEs do not have adequate access to financing and resultantly SMEs are relying primarily on informal sources of finance. According to another estimate $54 \%$ of total advances portfolio belongs to corporate sector and SMEs only cater $19 \%$ from total advances portfolio of banking and other specialized institutions.

According to another study, availability of sufficient funds contributes $25 \%$ to the success of SMEs (Ogujuiba et al, 2004). Every business entity is financed either through debt or equity or the combination of both and these both types of financial resources are sources from formal finance sources and informal finance sources (IFS) respectively. (Gbandi and Amissah, 2014).

Various previous researchers have identified commercial banks, development finance institutions, specialized banks, microfinance banks, international development agencies etc as formal finance sources and borrowing through personal contacts like from friends, family relations, corporatives, landlords, money lenders as informal financial sources. It is pertinent to mention here that for SMEs, due to liquidity constraints informal financial sector is very important source of finance for SMEs. (Gbandi \& Amissah, 2014) 


\subsection{Formal Finance Sources (FFS) for SMEs in Pakistan}

The major source of formal financing for SMEs in Pakistan includes Asian Development Bank (ADB), Federal Bank of Corporatives, Commercial Banks and Domestic Private Banks having SME advances portfolio percentage of 35\%, 4\%, 49\% and 12\% respectively (Hassan, 2008).

The same study also highlighted the fact that despite good number of formal financial institutions farmers and poor agriculture workers obtained only $6 \%$ of their credit from formal finance sector. Naveed (2012) concluded from his research that majority of SMEs get funds for their businesses from personal savings or through other informal credit channels and these enterprises are the real means for mobilizing their savings. Rural households resultantly save their surplus or extra money as they found themselves getting rid of interest rates and also there is no proper diversified branch banking network.

Following are some of the formal finance sources (FFS) for SMEs in Pakistan.

\subsubsection{SME Bank}

SME bank is a specialized bank for promoting SMEs in Pakistan. It was established in Jan 1, 2002 as a result of amalgamation of Regional Development Finance Corporation and Small Business Finance Corporation for exclusively cater the needs of niche market that is SME sector that will help ignite SME development. It not only provides loan facilities including running finance, term loans etc at varying rates and loan limits but also deposits products including current and PLS accounts, term deposits etc.

As per SME bank audited financials for the year ended 31.12.2013 total outstanding advances were $2852 \mathrm{M}$. The year 2011 and 2012 also show high outstanding advances figures of $2718 \mathrm{M}$ and $2855 \mathrm{M}$ respectively, which are significant figures and shows SME bank's commitment towards SME development. It is analyzed that there is only one SME bank (a specialized institution established exclusively for the SME development in Pakistan) acting as a prototype for other intended SME banks. Based on the quantum of SMEs in Pakistan it is concluded that just one specialized bank that is 'SME bank' is not able to cover the whole vista of SME financing in Pakistan.

\subsubsection{Commercial Banks}

Commercial banks are another formal financial source for SMEs. All commercial banks and especially 5 big banks have significant contribution in SME financing. As per estimate provided by SBP in first quarter of 2008 regarding SMEs, that $43.40 \%$ share of SME finance portfolio is from 5 big banks including National Bank of Pakistan (NBP), Muslim Commercial Bank of Pakistan (MCB), United Bank of Pakistan (UBL), Allied Bank of Pakistan (ABL) and Habib Bank Limited (HBL) and other private banks constitute $56.60 \%$ share of SME outstanding advances.

Another estimate that is provided by State Bank of Pakistan (SBP) in its Development Finance Review (2012), total outstanding SME finance is 247.9B. So it is concluded that banks' considerable portion of financing is SMEs.

In addition to above mentioned most appropriate and important formal financial sources for SMEs, there are many other institutions/ stakeholders which are making efforts for the SME development and growth in Pakistan, only few to include. 


\subsubsection{State Bank of Pakistan (SBP)}

State Bank is the regulator for financial institutions in Pakistan. It has a very significant role for SME development and growth in Pakistan like extending advisory services, providing enabling and viable business environment, guarantee schemes etc. Many milestones have been achieved by SBP and striving hard for achieving more as far as progress in SME development is concerned. Some of the milestones that have been achieved by SBP are as follows;

Keeping in view the importance of SME sector in Pakistan whereby more than $90 \%$ of businesses belong to SME sector has made separate prudential regulations (PRs) for SME sector after analyzing that PRs for corporate/ commercial are catering the needs and requirements of corporate sector only. Recently SBP has made reforms in its existing PRs regarding SMEs after observing that financial institutions' focus while serving this sector is tilting towards large scale enterprises thus neglecting small enterprises due to non availability of important financial data and risk of failure associated with small businesses. For this to give boost to the efforts being made for improving small enterprises' (SEs) access to finance, small enterprise (SEs) and medium enterprises (MEs) are separately defined. SBP has also made reforms in its existing eCIB portal after assembling the data and current status of the small borrowers thus making eCIB system/ information more appropriate and effective.

\subsubsection{Small and Medium Enterprises Development Authority (SMEDA)}

Keeping in view the huge potential of SME sector in Pakistan there was a need for such a advisory and technical support institution that is solely focusing on the development and growth of SME sector in Pakistan as in other developing countries like China, India, Nigeria etc and for that matter Small and Medium Enterprises Development Authority (SMEDA) has been established in 1998. SMEDA is an institution that provides advisory services to the SMEs in Pakistan. Some of the roles of SMEDA for economic growth and development are as follows;

o Providing business support/ promotion to the SMEs.

oExtending marketing support.

oAdvisory services for government on fiscal and monetary issues relating to SMEs.

o Conducting seminars, workshops and training programs for SMEs.

oDonor assistances for SME development through programs and projects.

\subsubsection{Trade Development Authority of Pakistan (TDAP)}

It is another agency having old name of Export Promotion Bureau for business promotion and support. Following are some of the roles of Trade Development Authority of Pakistan (TDAP) that are specific to SMEs.

oProviding advisory services and business support for the SMEs.

oFocusing on international trade development.

oProviding marketing support for SMEs to capitalize the opportunities of exporting value added products.

\subsubsection{International Financial Agencies/ Institutions}

There are many other international financial agencies that are playing an important role for SME development and growth in Pakistan. These agencies or institutions include; World 
Bank (WB), International Monetary Fund (IMF), International Finance Corporation (IFC) etc. Some of the roles of these international agencies/ institutions to include;

oProviding donations/ loans etc on concessionary rates.

oProviding advisory services.

oHelp in providing level playing field for the SMEs.

oProviding value added resources.

oLocal and global best practices and opportunities.

\subsection{Informal Finance Sources (IFS) for SMEs in Pakistan}

As far as SMEs are concerned informal finance sources are very important sources of finance for them. The credit necessities of rural and agrarian people are fulfilled by this source that is Informal Finance Source (IFS). Further, enterprises may choose between IFS and FFS for getting financing facilities based on the source's stability, independence and cost (Pirvu, Vasilesw and Meheditu- 2013). The informal finance source is of two types;

oFriends and family relatives.

oLandlords, merchants and shop keepers.

According to an estimate provided by Mehboob Ul Hasan, 2008 that $61 \%$ of informal finance source is come from friends and family members or relatives, $30 \%$ from landlords, merchants and shopkeepers and $2.12 \%$ from professional money lenders. In this sector normally credit of small amount with small time period is given having interest rates varying from $0 \%$ (when borrowed from friends and family members) to usury- a very high and unjust rate of interest (when borrowed from money lenders).

According to an estimate provided by Government of Pakistan more than $90 \%$ of rural SMEs including farmers obtain credit from informal finance source. As pointed out by Sherazi and other co- authors (2012) that financing to SMEs near banks or other specialized institutions is of low demand further SMEs businesses prefer to hire finance from their own sources like savings etc or through their friends/ relatives because opportunity cost of equity financing based on financing facility obtained from friends/ relatives is very low compared to bank financing. Kon and Storey (2003) has pointed out that if borrowers (SMEs) have best business plan they do not ask bank for finance their business due to their scariness of rejection of such proposal. The same fact has also pointed out by Kauser, Durrani, Hussain and Hassan (2012) that small borrower having best business proposal do not go to the bank to finance his/ her proposed business proposal because the prospective borrower is scared from banks' attitude and policies and practices. Nkuah, Tanyeh and Gatten, 2013 pointed out that due to bureaucratic lending policies and practices of banks or other financial institutions, SMEs are more relying on informal financial sources. So it is all leading towards the fact that there is a financial markets' inefficiency to serve the SMEs in a formal way by extending credit facilities without hectic and time consuming formalities and it is a classic case of market failure.

One important form of informal finance source (IFS) is the equity participation that is used by tenants and subsistence farmers and as cited by Mehboob U1 Hassan (2008), it is the most common means of informal source of finance for farmers or rural SMEs. Money lenders provide credit mainly for purchasing fertilizers, rental machinery and for working capital requirements. Money lenders though require no collateral but take the share in the profit at time of harvesting. Further interest rate is more than 5 times higher than interest rate from formal sector. (Mehboob UL Hassan, 2008) 
Based on the facts and figures as well as comments/ analysis of different scholars/ researchers/ practitioners mentioned above it can be said that SMEs play a pivotal role for economic growth and development for a country like Pakistan. In Pakistan where there are 3.2M businesses of which 3M are SMEs thus constituting more than $90 \%$ of business stakes and having economic contribution more than $30 \%$ to GDP, $25 \%$ to country's total earnings and employing more than $70 \%$ of labour force (IFC, 2012), SMEs are of paramount importance. Keeping in view the importance of SMEs, governments of Pakistan, SBP, SMEDA and all other stakeholders have significant contributions to reap the real benefits and fruits of SME sector which have been discussed and made part of this research paper.

It is worth mentioning here that SME sector in Pakistan is facing many issues and challenges as a result of which Pakistan is not able to get the real fruits of having good number of SMEs. In following section some issues/ challenges that are facing by this sector have been discussed.

According to different scholars/ academicians/ researchers following are some of the major challenges/ issues that are facing by SME sector;

1. Improper infra-structure.

2. Regulatory requirements difficulties.

3. Shortage of skilled HR.

4. Non competitive products.

5. Lack of entrepreneurial expertise.

6. Shortage / irregular availability of financing facilities.

7. Inability to meet financing formalities / credit conditions.

8. Lengthy documentation procedure.

9. Small scope of business.

10. Risk of default.

Of all the issues/ challenges mentioned above non- availability of sufficient financial facilities are the most important concern for all the stakeholders as evident by many researches including (Sherazi, Iqbal, Asif, Rehman and Shah- 2012 and Kousar, Durrani, Hussain \& Hassan- 2012). Although there is a credit constraints issue in the financial market but actually banks or other financial institutions are reluctant to provide financing to SMEs due to many reasons including small/ limited scope of operations/ risk of default, lack of proper documentation especially financial statements to name a few. This fact has also been highlighted by Sherazi with his co-authors (2012) and Kauser with co- authors (2012) that rising interest rates due to inflation factor and fluctuating economic conditions further due to their small scale of operations and risk of failure associated with SME business, banks are resilient in providing loans to SMEs as they are risk aversive while extending credit facilities to SMEs.

It is also quite evident by the fact that on YoY basis bank's financing to SMEs has been declined as mentioned in IFC report 2012 that bank's financing to SMEs was Rs. 292.5B which decreased to Rs. 247.9B in 2012 thus showing $15.3 \%$ declining trend. However according to one study more the sources of finance the more the chance of investments, growth and development in country (Pirvu, Vasilesw \& Mehedintu, 2013). More and more sources of finance are major factor of development because it gives rise to more capacity to invest.

Most of the SMEs are facing insufficient access to finance due to the requirements of financial institutions for fulfilling hectic documentation as it is a known fact that SMEs are not capable of maintaining financial statements and near banking institutions it is the primary document for having credit facility, so due to the absence of such document financing 
requests are declined by the banks in majority of the cases. This fact has been pointed out by Kousar, Durrani, Hussain \& Hassan (2012) that financial documents are imperative for SMEs to have access to finance from banks and other financial institutions.

Banks are reluctant to provide financing facilities to SMEs because they require collaterals for securing their loans. As pointed out by Mehboob UL Hassan, 2008 in his research paper that mostly owners of SMEs in rural areas especially, are illiterate people and are unable to fulfill the documentation requirements further there is lack of financial linkage between financial institutions and SMEs due to very few bank branches in rural areas and improper financial infrastructure which leads the borrowers to avail financial facilities from informal sources of finance as they are not in position to fulfill the requirements/ terms and conditions of financing facilities during the term of loan because they have to cover a lot of distance in reaching the branches thus increasing their time and costs of availing the financial facilities from formal financial sources.

In the review of literature (mentioned above) sources of finance available for SME sector of Pakistan and problems/ challenges/ issues associated in having credit facilities especially from formal sources of finance and role that all stakeholders have played yet for SME sector development has been mentioned in detail. In the following section main findings/ conclusion/ recommendations of the research paper has been given.

\section{CONCLUSION}

From the foregoing analysis and findings, I have derived an empirical conclusion that SME sector is a backbone of Pakistan economy as this sector plays a significant role for economic development and considered as a survival in worst economic condition for Pakistan. According to IFC (2012), approximately there are 3.2M businesses in Pakistan of which 3M are SMEs thus constituting more than $90 \%$ of business stakes and having economic contribution of more than $30 \%$ to GDP, $25 \%$ to country's total earnings and employing more than $70 \%$ of labor force. Keeping in view the importance of SME sector in Pakistan, many significant milestones have been achieved by all the stakeholders including establishment of Small and Medium Enterprises Development Authority (SMEDA), SME bank, SBP SME department, Prudential Regulations of SBP exclusively for SMEs and various government/ and other stakeholders' initiatives from time to time. Despite of all the significant efforts made by the stakeholders for its effective growth and development this sector is facing many challenges including improper infra-structure, regulatory requirements difficulties, shortage of skilled HR, non competitive products, lack of entrepreneurial expertise, shortage / irregular availability of financing facilities, inability to meet financing formalities / credit conditions, lengthy documentation procedure, small scope of business and risk of default. Access to credit is one of the major issues that are facing by this sector, while conducting the research it was found that financing options for SMEs are numerous but access to the finances is difficult despite various government initiatives.

SMEs have formal financial sources (FFS) including banks and other financial institutions and informal financial sources (IFS) including financing facilities extended by friends, relatives, shop keepers, money lenders etc. Banks and other financial institutions are reluctant to provide financial facilities to SMEs and especially SEs (small enterprises) due to their small scope of business, risk of their failure or default, collateral requirements and lack of proper documentation especially non- availability of financial statements. It is also quite evident by the fact that on YoY basis bank's financing to SMEs has been declined as 
mentioned in IFC report 2012 that bank's financing to SMEs was Rs. 292.5B which decreased to Rs. $247.9 \mathrm{~B}$ in 2012 thus showing $15.3 \%$ declining trend. According to one estimate $54 \%$ of total advances portfolio belongs to corporate sector and SMEs only cater $19 \%$ from total advances portfolio of banking and other specialized institutions.

Due to banks' and other financial institutions' reluctance in extending credits to SMEs, they go for informal financial sources. According to an estimate provided by Government of Pakistan more than $90 \%$ of rural SMEs including farmers obtain credit from informal finance sources. There rate of interest is ranging from $0 \%$ (when financial facility is extended by friends/ relative) to usurious rates (when financial facility is extended by money lenders). SMEs major issue of tilting towards informal sources of finance is the lack of access to finance from formal financial sources as formal institutions are reluctant to serve this sector. Following are some recommendations for addressing the financing needs of SMEs;

oAs SMEs (especially located in rural areas) in majority of the cases use informal financial sources and its own savings so financial institutions should establish more and more branches in rural areas for deposit mobilization as there is a huge potential of having significant figure of deposits in shape of savings.

oBanks and other financial institutions should make every effort for completing the documentation requirements for SMEs as the owners of this sector are normally illiterate people so banks and other financial institutions should help them in fulfilling all the requirements rather than to reject their finance requests based on non- fulfillment of documentation formalities.

oAll stakeholders and especially government and regulator (SBP) should provide enabling and more appropriate and friendly business environment to SMEs.

oSBP and other stakeholders should arrange workshops, seminars and training programs for SMEs.

oSavings in informal finance sources should be encouraged through regulation, government intervention through active participation of community and banking institutions.

For an effective SME sector that can be able to contribute in economic development and growth of any country, sufficient availability of finance is the key factor of success so it is suggested to take into account recommendations (mentioned above) to cope the issue of insufficient availability of financial resources for SME sector in Pakistan.

\section{References}

[1] Sas Aruwa (2013), "Financing Options for Small and Medium Scale Enterprises in Nigeria".

[2] Cerasela Pirvu and Laura Giurca Vasilescu and Anca (2008), "Banking financing for Romanian SMEs- Challenges and Opportunities".

[3] Rehana Kousar, Anum Durani, Farheen Zahra Hussain and Masood ul Hasan (2012), "Investigation of Banker's Lending Criteria to SMEs and Assessment Thereoff".

[4] Syed Kamran Sherazi, Muhammad Zubair Iqbal, Muhammad Asif, Kashif-ur-Rehman and Syed Saad Hussain Shah (2013), "Obstacles to Small and Medium Enterprises in Pakistan, Principal Component Analysis Approach”.

[5] Kashif Hamid and Abaidullah (2006), "Financing the Small and Medium Enterprises in Faisalabad". 
[6] E.C.Gbandi \& G. Amissah (2014), "Financing Options for Small and Medium Enterprises (SMEs) in Nigeria".

[7] Joseph Kofi Nkuah, John Paul Tanyeh \& Kala Gaeten (2013), "Financing Small and Medium Enterprises (SMEs) in Ghana: Challenges and Determinants in Accessing Bank Credit".

[8] Mehboob UL Hassan (2008), "Microfinance in Small and Medium Enterprises (SMEs) in Pakistan: Practices and Problems in the Prevailing System and Prospects for Islamic Finance".

[9] State Bank of Pakistan, Prudential Regulations for SMEs.

[10]International Finance Corporation quarterly report 2012.

[11] State Bank of Pakistan quarterly report for SMEs 2008. 